\title{
Agroforestry-The Next Step in Sustainable and Resilient Agriculture
}

\author{
Matthew Heron Wilson ${ }^{1}$ and Sarah Taylor Lovell ${ }^{2, *}$ \\ 11105 Plant Sciences Laboratory, Department of Crop Sciences, University of Illinois at Urbana-Champaign, \\ Urbana, IL 61801, USA; mhwilso2@illinois.edu \\ 21009 Plant Sciences Laboratory, Department of Crop Sciences, University of Illinois at Urbana-Champaign, \\ Urbana, IL 61801, USA \\ * Correspondence: stlovell@illinois.edu; Tel.: +1-217-244-3433
}

Academic Editor: Sean Clark

Received: 30 April 2016; Accepted: 12 June 2016; Published: 18 June 2016

\begin{abstract}
Agriculture faces the unprecedented task of feeding a world population of 9 billion people by 2050 while simultaneously avoiding harmful environmental and social effects. One effort to meet this challenge has been organic farming, with outcomes that are generally positive. However, a number of challenges remain. Organic yields lag behind those in conventional agriculture, and greenhouse gas emissions and nutrient leaching remain somewhat problematic. In this paper, we examine current organic and conventional agriculture systems and suggest that agroforestry, which is the intentional combination of trees and shrubs with crops or livestock, could be the next step in sustainable agriculture. By implementing systems that mimic nature's functions, agroforestry has the potential to remain productive while supporting a range of ecosystem services. In this paper, we outline the common practices and products of agroforestry as well as beneficial environmental and social effects. We address barriers to agroforestry and explore potential options to alter policies and increase adoption by farmers. We conclude that agroforestry is one of the best land use strategies to contribute to food security while simultaneously limiting environmental degradation.
\end{abstract}

Keywords: agroforestry; organic agriculture; agroecology; alley cropping; silvopasture; riparian buffer; forest farming; windbreak

\section{Introduction}

Agriculture shapes our planet in profound ways. Roughly $38 \%$ of the land surface of the earth is used to grow food, making agriculture the largest anthropogenic land use [1]. Expansion in agricultural land is the leading cause of deforestation and native habitat loss [2,3], a situation that has led to declines in wildlife, including birds [4], insects [5], and mammals [6], some of which are now considered endangered species [2]. Nutrient leaching from fertilizer results in the eutrophication of waterways, leading to oxygen deficient "dead zones" in water bodies around the world $[7,8]$. Agriculture is the largest human-caused contributor to the greenhouse gas emissions implicated in climate change [1,9].

Humans are not exempt from these effects. Pesticides in measurable quantities can be found in many environments, including the human body $[10,11]$. In the United States alone, the human health cost of pesticide poisoning has been estimated at $\$ 1.2$ billion per year [12], and excess nitrate in drinking water caused by over-fertilization can cause illness and is costly to clean up [13-15].

In addition to environmental and human impacts, there are disconcerting implications for the resilience of our agricultural systems [16]. Worldwide, just fifteen crops produce $90 \%$ of food calories, with wheat, rice, and maize alone supplying $60 \%$ [17]. A majority of these crops are grown in vast tracts of annual monocultures which have a high risk for pest and disease outbreaks $[18,19]$. The Irish potato 
famine of 1845-1850 contributed to the deaths of over a million people and is a stark reminder of what can happen when disease destroys a single crop that is relied upon too heavily [20]. These monocultures require yearly replanting, high inputs, and weed control [21], and it has been suggested that this cycle of plant-fertilize-spray tends to serve the interests of the large agribusiness companies who supply the inputs for this system more than furthering the goal of feeding the world [22].

The long-term sustainability of any agricultural system requires that soils stay productive and that necessary inputs remain available in the future. However, soil loss occurs more rapidly than soil creation in many agricultural landscapes [23], and the soil that remains tends to decline in quality [24]. Heavy reliance on fossil fuels in the form of liquid fuel and fertilizer makes agriculture subject to fluctuations in fuel costs and supply [25]. One-way fertilizer nutrient flows simultaneously cause pollution and scarcity. Phosphorus is one example: this essential plant nutrient is expected to become increasingly expensive to mine and process, while, at the same time, phosphorus runoff causes eutrophication of water bodies [26,27].

In the near future, our agricultural systems will also have to adapt to a changing climate that is expected to bring more extreme weather events like droughts and floods, in addition to increases in outbreaks of diseases and pests [28]. The changes will be more severe in the developing world, where poverty hinders people's ability to adapt [29,30]. The Dust Bowl of the 1930s is an example of destructive agricultural practices paired with an extreme drought that led to catastrophic consequences [31]. Agricultural overreach along with the inability to adapt to changes in climate has toppled civilizations, from the ancient Mesopotamians to the Mayans [32,33].

\section{The Rise of Organic Farming}

Organic agriculture arose as an alternative to the conventional farming paradigm, pioneered by early practitioners such as Rudolf Steiner in Europe in the 1920s, Sir Albert Howard and Lady Eve Balfour in the UK and J.I. Rodale in the United States in the 1940s, and Masanobu Fukuoka in Japan in the 1970s and 1980s [34]. Several terms were used in these agricultural movements, including "organic", "biodynamic", "ecological", and "biological" [35]. In 1990, the United States Department of Agriculture (USDA) standardized the definition of organic production in the US, giving consumers and producers alike a common understanding of what "Certified Organic" means [35].

Although differing slightly by country and certifying agency, the main guidelines for organic management prohibit the use of synthetically produced pesticides and fertilizers, genetically modified organisms (GMOs), and the prophylactic use of antibiotics in livestock feed. Soil quality must be maintained through various practices such as crop rotation, cover cropping, or mulching [36]. Animals under organic management must be fed certified organic feed and ruminants must have access to pasture for a prescribed number of days [36]. Fertility is typically maintained by leguminous cover crops, applications of manure and compost, biologically derived inputs such as blood and feather meal, and mined mineral substances [36]. Weeds in organic grain and vegetable systems are usually controlled through tillage, though cover cropping and crop rotation also play an important role in breaking up weed cycles [37]. Pests control entails providing habitat for beneficial predators, selecting resistant plant stock, and using biologically derived pesticides as a last resort when needed [36].

The guidelines of organic production usually lead to more sustainable outcomes on the ground. Organic farms foster higher biodiversity than conventional farms, including insects, plants, soil biota, and even birds and larger animals [38-40]. Often, organic farms are more diverse in their cropping systems due to the inclusion of livestock and longer crop rotations [10]. The use of mechanical and cultural control methods for weeds and other pests can leave low levels of these populations that further contribute to biodiversity [40]. Soil quality tends to improve under organic management based on measurements of soil organic matter $[39,41]$, though no-till conventional agriculture measured highest of all in some studies [9]. Although organic yields typically lag behind conventional yields [42], in drought years the opposite has been shown, which is attributed to the higher water holding capacity 
of soils under organic management [43,44]. Overall, organic production uses less energy per production unit due to the high energy costs of conventional fertilizer and pesticides [39,44,45].

Worth noting is the fact that, although organic certification makes hard distinctions about the use of pesticides, synthetic fertilizers, and GMO technology, a wide spectrum of practices are available for both conventional and organic producers that have beneficial environmental outcomes. Cover cropping, integrated pest management, application of manure and composts to build soil organic matter, crop rotation, and the integration of livestock and crops are important tools that should not be overlooked when considering impacts. Indeed, in some studies that compared organic vs. conventional crop systems, the authors conclude that improvements under organic management were likely due to practices like manure application and cover cropping that were included in the organic system which could be employed in a conventional system to similar effect [46-48].

\section{Challenges in Organic Agriculture}

Even with the good intentions of organic certification practices, most organic crop production systems utilize the same basic methodology as conventional farming, and therefore can have some of the same negative consequences. The pattern of cultivating annual monocultures that require yearly replanting, application of fertilizer, intensive weed control, and highly mechanized equipment to accomplish the work remains relatively unchanged, especially at scales larger than small market gardens [49]. The undesirable conventional tools are simply swapped out for those that are more benign: organic seeds for GMO seeds, cultivation or mulch instead of herbicides for weed control, and cover crops and manure for fertilization instead of fossil-fuel derivatives [36]. Although these changes can lessen environmental impacts, they may not eliminate them.

The issue of nitrogen leaching offers a good example of environmental impacts that are not eliminated entirely. Even though some studies show an improvement in nitrate leaching under organic management, the levels may still contribute to groundwater pollution. Pimentel et al. compared three rotations with differing sources of nitrogen: an organic rotation with legume cover crops, an organic rotation with animal manures, and a conventional rotation utilizing synthetic fertilizers. They found that leachate samples for all three treatments sometimes exceeded the $10 \mathrm{ppm}$ regulatory limit for nitrate concentration in drinking water. The organic animal, organic legume, and conventional rotations lost $20 \%, 32 \%$, and $20 \%$, respectively, of the nitrogen applied to the crops in the form of nitrate [44]. In Swedish studies, Bergström et al. concluded that organic sources of nitrogen leached more than conventional fertilizers. They attributed this to the fact that the manures and legume cover crops released the most nutrients during fallow periods or at times that did not sync with nitrogen demand of the crop [50].

Even though soil quality can improve under organic management relative to conventional management $[39,44,51]$, soil loss and degradation are still risks due to the fact that tillage is required for weed control and for incorporating biomass from cover crops $[37,46]$. Tillage has been shown to have adverse effects including compaction, erosion, and lowering of biological activity in the soil [23,52,53]. As reported in Arnhold et al., studies comparing erosion in organic and conventional systems have had variable results that depend upon the crop rotation, crops used, and tillage systems. The authors' study in mountainous regions in Korea concluded that soil loss under either conventional or organic management was too high for sustained productivity [54].

Recognizing the benefits of reducing tillage, there has been interest in adapting no-till techniques for organic farming [37]. The process usually entails growing a cover crop ahead of the main cash crop, then crushing it down mechanically and planting through the residue [55]. If done correctly, weeds are suppressed by the mulch and no cultivation is needed for that crop. However, it can be a challenge to grow the necessary biomass in the cover crop to provide effective weed control, and the technique may not be possible in water-limited environments due to water competition by the cover crop [37]. Perennial weeds pose a particular problem, as they are typically able to grow through the mulch $[37,42,55]$. 
Studies exploring the impact of organic agriculture on greenhouse gas emissions have shown mixed results $[35,41,56]$. When measured on a per area basis, organic systems may fare better than conventional systems, but when the yield gap in organic is taken into effect, the emissions may be higher per unit of output [39,48]. Even when soil carbon increases, other gasses such as nitrous oxide are emitted by annual systems that contribute to climate change, negating potential benefits [9].

Differences in yields between organic and conventional systems may also have indirect environmental implications. Organic systems are generally agreed upon as less productive, with an average decrease in yield of around $20 \%$ to $25 \%$, though the literature shows ranges anywhere from $5 \%$ to $50 \%$ depending upon the crop, soils, intensity of management, and methods by which the study was conducted $[38,42,57]$. Critics argue that under organic management, more land would need to be put into agricultural production in order to maintain global food security. This would result in deforestation and other habitat loss, leading to an overall negative environmental outcome $[42,58]$.

Given these challenges within the organic/conventional debate, there seems to be an opportunity to evaluate additional tools and techniques that may yield other possible solutions. Instead of an "either-or" approach to thinking about our agricultural landscapes, a "yes-and" mentality might be more useful. Indeed, many have called for a multidisciplinary, multifunctional approach to designing agroecosystems $[24,39,59,60]$. In terms of feeding the world while sustaining the planet, perhaps Foley enunciates this best: "No single strategy is sufficient to solve all our problems. Think silver buckshot, not a silver bullet" [1] (p. 65).

\section{Agroforestry as a Transformative Solution}

One multifunctional approach for our food system is agroforestry, the intentional combination of trees and shrubs with crops or livestock. Agroforestry has been recognized for nearly half a century as a sustainable agricultural practice [61], and the concept of integrating trees into the agricultural landscape is as old as the practice of cultivating land. The beneficial outcomes of agroforestry include reductions in nutrient and pesticide runoff, carbon sequestration, increased soil quality, erosion control, improved wildlife habitat, reduced fossil fuel use, and increasing resilience in the face of an uncertain agricultural future [21,62-67]. In short, adding trees and other perennials to a landscape can help mitigate many of the harmful effects of agriculture. The fact that it can simultaneously provide economic, ecological, and cultural benefits gives agroforestry great potential as a land use strategy in both the developing and developed world [68].

\subsection{Agroforestry Practices and Products}

In addition to the environmental benefits, agroforestry can supply products such as timber, crops, fruits, nuts, mushrooms, forages, livestock, biomass, Christmas trees, and herbal medicine [69]. A diverse portfolio of products would allow revenue streams to be spread out over the short-term (crops, forage, livestock, mushrooms, certain fruits like currants), medium-term (nuts, fruits such as apples or persimmons, biomass, medicinal plants), and long-term (lumber, increased property value). This diversity of products can also reduce risk for farmers, though it may require creative marketing [69].

Different types of agroforestry are practiced across the world. Tropical agroforestry has traditionally enjoyed more focus and has been more widely adopted than temperate agroforestry. Systems like shade-grown coffee and tea are well developed, and the availability of hand labor makes some tropical agroforestry practices more practical than in areas where machine harvesting is more common $[31,70]$. Culturally, agroforestry has played an important role in both indigenous tropical areas and in temperate places like Europe, though land abandonment and agricultural intensification in northern areas has led to declines in traditional agroforestry practices [71]. This review focuses primarily on temperate agroforestry.

There are five generally recognized agroforestry practices promoted in the temperate zone, especially in North America: alley cropping, silvopasture, riparian buffers, windbreaks and forest 
farming $[67,69]$. These practices fit within a variety of cropping systems, topographies, and climatic zones.

\subsubsection{Alley Cropping}

Alley cropping involves growing field crops between rows of trees [72]. The trees can be grown for timber or fruits and nuts, while the alley crops can include a variety of grains, vegetables, or forages cut for hay. The crops provide short-term income while the trees provide longer-term revenue. The tree and crop species also may interact in ways that allow increased production due to the different niches that the trees and crops occupy [73]. For example, one study in France showed walnuts and winter wheat to be good companions because they grow at different times of the year and have differing rooting depths. The researchers concluded that the system produces $40 \%$ more product per given area than if the two crops were grown separately [74].

\subsubsection{Silvopasture}

Silvopasture incorporates livestock into an intentional mixture of trees and pasture. Silvopasture is different from just "grazing the woods", because the spacing of the trees is carefully planned to allow enough sunlight for the forages below, and the livestock are kept from damaging the trees. The trees offer protection for livestock through shade during the heat of the summer and wind reduction in the cold winter $[75,76]$. Additionally, the pasture quality in partial shade may increase, although it is usually slightly less productive in terms of biomass [77]. Livestock grazed on silvopasture versus open pasture show equal gains [76]. If the trees are also being grown for timber, the long-term bottom line of the farmer will improve without compromising current production [76].

\subsubsection{Riparian Buffers}

Riparian buffers are planted areas around waterways that are at risk from erosion, nutrient leaching, or habitat loss [78]. Usually there are two or three "zones" of vegetation that vary in composition based on the proximity to the waterway, slope, and producer needs [69]. Riparian zones tend to be marginal for agricultural production, making them prime candidates for alternative uses. There has been concerted effort by the United States Department of Agriculture (USDA) to implement conservation practices on areas around waterways due to their beneficial impact on water and soil quality. The Environmental Quality Incentive Program (EQIP) through the Natural Resources Conservation Service (NRCS) and Conservation Reserve Program (CRP) through the Farm Service Agency (FSA) are examples of some government funded initiatives [79].

\subsubsection{Windbreaks}

Windbreaks, also known as shelterbelts, were recognized early on as a useful agroforestry practice. Windbreaks prevent wind erosion, provide habitat for wildlife, and can increase water availability to nearby crops due to lower evapotranspiration and the effects of catching snow [75]. More water can mean higher production, leading to important economic benefits to farmers [80]. On a farmstead, windbreaks can decrease the heating and cooling needs for living and working spaces by reducing indoor air exchange caused by wind [81].

The Dust Bowl years in North America led to the U.S. government initiating the Prairie States Forestry Project, a massive shelterbelt stretching from Canada to Texas [75]. Another notable example is China's Three-North Shelter Forest Program, the world's largest afforestation effort [82]. Started in 1978 and expected to be completed in 2050, it is known as "China's Great Green Wall" [82]. Similar strategies have been employed in Russia, northern Europe, Australia, New Zealand and other countries $[75,80,83]$. 


\subsubsection{Forest farming}

Forest farming includes practices such as raising mushrooms, harvesting medicinal herbs like ginseng and goldenseal, and marketing woody ornamental material [69]. This agroforestry approach usually occurs in established forests that are grown for timber and allows for income generation without major disturbance [84]. Management of forest farming systems can range from intensive to minimal, depending on the product and desired market. For example, woods-grown ginseng may involve extensive site preparation, fertilizer, tillage, and fungicides that can increase yields but are costlier and therefore riskier. Alternately, wild-simulated ginseng may involve simply raking leaves back, planting seeds, and letting the ginseng grow for several years until it is ready to harvest [69].

It is noteworthy that, of the five practices, only alley cropping and silvopasture are typically practiced on land that is suitable for conventional agriculture. Even then, conventional cropping is often continued for several years before the trees are fully grown [69]. Riparian buffers, windbreaks, and forest farming usually occur on field margins or on land not suitable for farming, although, in some cases, may require setting aside some cropland to obtain the required width to be effective [85]. These practices therefore tend to complement, rather than compete with, existing production systems and may provide ways to contribute to food security by using resources that are otherwise underutilized.

In practice, agroforestry can contribute to either conventional or organic systems. In either case, the beneficial effects of agroforestry can improve environmental outcomes beyond what is already possible within each system. In this way, agroforestry may be able to address some of the challenges outlined earlier for organic agriculture, including soil loss, greenhouse gas emissions, and nutrient leaching. The next section summarizes these benefits, as promoted in the agroforestry literature.

\subsection{Benefits of Agroforestry}

Agroforestry has positive effects on soil and water quality. Soil quality is improved by increased levels of organic matter, more diverse microbial populations, and improved nutrient cycling, which may increase crop productivity and the ability to cope with drought $[65,86,87]$. The water quality benefits occur as non-point source pollution from row crops is reduced by incorporating agroforestry vegetative buffer strips [88-90]. On a "paired" watershed study in Missouri, agroforestry and grass buffer strips reduced phosphorus and nitrogen loss from a corn-soybean rotation [88]. The perennial vegetation increases above-ground biomass that slows runoff and can trap as much as $95 \%$ of the sediment at risk of being lost [91], while the below-ground roots can take up $80 \%$ or more of excess nutrients as well as hosting microbial populations that can break down pesticides [68,90,92].

The increase in soil organic matter in the form of carbon not only improves the health of the soil, but it can also help reduce atmospheric carbon dioxide that is implicated in climate change [23]. Compared to a monoculture of crops or pasture, adding trees and shrubs to an agricultural landscape increases the level of carbon sequestration [65,93]. Kim et al. did a meta-analysis on greenhouse gas emissions in agroforestry and showed an overall mitigation of $27 \pm 14$ tons $\mathrm{CO}_{2}$ per hectare per year. Biomass accounted for 70\% of sequestered carbon, with the remaining $30 \%$ sequestered in the soil [94]. A North American analysis performed by Udawatta and Jose showed that agroforestry practices implemented on a modest scale could potentially sequester $548.4 \mathrm{Tg}$ carbon per year, enough to offset $34 \%$ of US emissions from coal, oil, and gas [85].

The mechanisms for increased carbon sequestration include better erosion control, more carbon being stored in woody perennials, reduced organic matter decomposition, and the fact that crop biomass is not harvested in agroforestry to the degree that it is in conventional systems [94].

The link between perennial systems and climate change may be an important one. Robertson et al. studied the global warming potential of several annual and perennial systems. They found that none of the annual cropping systems reduced global warming potential, whether conventional, no-till, reduced input, or organic. Although the cropping systems did accumulate carbon in the soil, the gains were offset by nitrous oxide emissions. However, the perennial and early successional forest treatments including alfalfa, hybrid poplar, and abandoned early successional sites all reduced global warming 
potential. Mid-successional and late successional systems stored less carbon per year as they matured. The authors concluded that the best option for mitigation was the early successional forest system [9]. Many agroforestry practices effectively mimic these early successional forests.

Reducing fossil fuel use is another important strategy for climate change mitigation [95]. Bioenergy is one avenue to reduce fossil fuel dependence, but there are concerns about using valuable cropland to grow crops for energy instead of food [16]. Currently, $40 \%$ of the U.S. corn harvest goes to producing ethanol, which seems counterproductive to the goal of reducing world hunger [16]. By producing biomass from trees in combination with food on the same land, agroforestry may be one way to contribute to a secure energy future without compromising food production capabilities $[96,97]$.

When comparing mixes of species (i.e., polycultures) with individual crops, a useful measure is the LER, or Land Equivalent Ratio [98]. This metric considers the yield of the polyculture and calculates the amount of land that would be required if the crops were grown separately. For example, when comparing loblolly pine and switchgrass mixes with pure stands of each crop, Haile et al. noted that, although each crop yielded less in the mix, the system produced an overall LER of 1.47 [99]. This means that if switchgrass and loblolly pine were grown separately, it would require $47 \%$ more land than the agroforestry system to grow the same amount of biomass.

Modeling of agroforestry systems in Europe using the Yield-SAFE (YIeld Estimator for Long-term Design of Silvoarable AgroForestry in Europe) model predicted LER values between 1-1.4 for scenarios in Spain, France, and the Netherlands, indicating higher productivity when integrating trees and crops than when grown separately [100]. In another study in Switzerland, agroforestry models focusing on walnut (Juglans hybrid) and wild cherry (Prunus avium) showed that in 12 out of 14 scenarios, mixing crops led to LER measurements higher than one. In addition, $68 \%$ of the Swiss financial scenarios were found to be more profitable than current practices [101].

When compared with conventional and organic monocultures, agroforestry contributes to the conservation of biodiversity. Adding trees, shrubs, and other perennial vegetation to an agricultural landscape provides habitat for greater numbers and more diverse populations of wildlife $[68,90]$. In addition to intrinsic value, biodiversity can provide useful services. More birds and predatory insects can help keep pests under control $[19,102]$. Habitat for pollinator species can mean better pollination of horticultural crops [103]. Even incidences of disease generally decrease in more diverse populations, for both plants and wildlife [104,105].

Livestock can benefit from agroforestry as well. Windbreaks protect animals from harsh winds, while shade provided by trees can increase comfort in the heat of the summer and may encourage more even grazing over a paddock [71]. Forest-based foraging systems for poultry and hogs can decrease the need for grain and provide surroundings closer to these species' natural habitat [106]. The cork oak dehesas of the Mediterranean are an example of a multifunctional landscape that has endured for hundreds of years, providing grass and acorns for grazing livestock and a valuable cash crop in the form of bark for making traditional corks [107].

Compared to annual monocultures, perennial polycultures like agroforestry are inherently more stable in the face of global market volatility and extreme climatic events [16]. In the event of fossil fuel scarcity, mature fruit and nut trees would continue to produce their products with relatively little interruption, though labor may have to be substituted for other inputs. Not only do agroforests sequester greenhouse gasses that are driving global climate change, they are also more resilient to its likely effects. Deeper rooting systems and improved infiltration and water storage lessen the impact of drought, while trees' abilities to pump excess water out of the soil as well as withstanding inundation better than field crops means they are also more resilient to floods [30].

Though often overlooked, there are additional cultural benefits to agroforestry. Many landowners value the preservation of nature, both for its beauty and for perceived benefits including a sense of improved health and the peace and quiet of a rural life [108]. Research shows that aesthetics provided by practices such as vegetative buffers are preferred by rural residents [109]. There are also opportunities for recreation, including bird watching, nature hikes, and hunting [110]. 


\section{Challenges to Agroforestry Adoption}

The opportunities for agroforestry are exciting, but not without challenges. Agroforestry adoption has been surprisingly low, considering the well-documented benefits [111-113]. Barriers have included the expense of establishment [114], landowner's lack of experience with trees [108,113], and the time and knowledge required for management [115].

Many farmers learn about new agricultural practices through extension personnel or agricultural product dealers, and these professionals typically do not have training or experience with agroforestry [116]. In addition, lack of established demonstration plots makes it hard for landowners to see these systems in action [3]. Since many of the useful outcomes from agroforestry are less tangible or longer-term, it may be difficult for landowners to envision them [117].

For agroforestry systems that produce edible products such as fruits and nuts, the logistics of harvest can be challenging. For agroforestry systems to be economically competitive, mechanization may be required for larger plantings [118]. This can be complicated if multiple fruit or nut species are grown.

Non-traditional markets and delayed profits may be another deterrent [108]. The economic feasibility of some agroforestry systems such as silvopasture have been shown to be profitable, whereas other practices such as biomass plantings or riparian buffers may need the development of markets that offer compensation for the ecosystem services provided in order to make financial sense $[62,97,119]$. Social change and networking will also play a role as mindsets evolve to include alternatives to the norm $[112,114]$.

\section{Moving Forward-Policy and Research Needs}

Given these challenges, a number of strategies have been proposed to move agroforestry forward. Policy changes could include increased funding for government cost-share programs for installing practices and credits for environmental services rendered, such as pollination and carbon sequestration $[68,97,113,116]$. Current USDA programs through the NRCS and FSA often stipulate that land set aside for conservation may not be harvested, but agroforestry systems could provide a harvestable product without compromising conservation potential. A policy change to allow non-destructive harvest of consumable products from such systems might encourage more farmers to adopt agroforestry practices, leading to better conservation outcomes [68].

Although it is reasonable that the majority of government funding goes toward major cropping systems such as corn and soybean, the fact that agroforestry has the capability to remediate the negative effects of these very systems suggests it should be given more attention [68]. Some of this support could be used for education through extension and university programs [120]. In fact, education may be the most important factor for adoption, as many studies on the adoption of conservation practices cite lack of access to information and technical assistance as one of the primary barriers $[3,108,116,120]$.

The opportunity to expand the production potential of agroforestry systems is underdeveloped. More research is needed to study the use of trees and shrubs to provide marketable products [121]. Recently, interest has grown in the development of multifunctional, edible polycultures that mimic natural ecosystems such as the native oak savannas of the Midwest [122]. These polycultures include multiple crops stacked together to take advantage of different ecological niches as well as to provide multiple streams of income [123]. For example, field trials at the University of Illinois at Champaign-Urbana were established to study a mixture of chestnuts, hazelnuts, apples, currants and raspberries. Control plots of a conventionally managed corn and soy rotation will allow for comparative analysis of a variety of environmental, ecological, and economic metrics. A large-scale, replicated study established in 2015 will look at different spatial layouts of these polycultures compared to monocultures of each species as they might be grown in a commercial orchard, in addition to being able to compare them to a corn/soybean rotation. Included in the treatments are plantings of native trees and shrubs that also have edible products, including aronia, elderberry, pecan, pawpaw, 
persimmon, plum, and serviceberry. This native edible plot explores what is possible within the confines of conservation easements that mandate the use of native species [123].

\section{Conclusions}

Various pathways have been proposed to safely and sustainably feed a growing population. Organic farming shows promise for lowering the use of agrichemicals and improving certain environmental and human health metrics, while proponents of conventional systems point out the advantages of using genetic engineering, fertilizers, and pest control in improving yields.

Broader strategies include limiting the expansion of farmland via deforestation, minimizing food waste, eating less meat, closing the yield gaps for underperforming cropland in the developing world, and more efficient use of resources like water, fertilizer, and fuel [1,48]. These efforts, and others, will be needed as part of a multi-faceted approach if we are going to successfully and sustainably feed the world.

Nature produces its bounty while requiring no plowing, no fertilizer, and no pest control—in fact, no inputs of any kind. It runs entirely on solar energy and generates no harmful waste products. Its biological diversity allows dynamic adaptation in the face of external change. If our agricultural systems can more closely mimic the functionality of nature, they can become more stable and resilient. Building such a system is without a doubt a challenging task, requiring a variety of tools. Agroforestry can provide the next step in sustainable agriculture by promoting and implementing integrated, biodiverse processes to increase yields, decrease harmful effects, and advance our understanding of the complex interactions involved in increasing food production while minimizing damage.

Acknowledgments: This work was made possible by the Jonathan Baldwin Turner Fellowship through the Department of Crop Sciences at the University of Illinois, Champaign-Urbana.

Author Contributions: Matthew Heron Wilson conducted the initial literature review and contributed a majority of the writing, and Sarah Taylor Lovell provided direction, editing, and proofreading, including writing revisions of some sections.

Conflicts of Interest: The authors declare no conflict of interest.

\section{Abbreviations}

The following abbreviations are used in this manuscript:

$\begin{array}{ll}\text { USDA } & \text { United States Department of Agriculture } \\ \text { NRCS } & \text { National Resources Conservation Service } \\ \text { FSA } & \text { Farm Service Agency } \\ \text { EQIP } & \text { Environmental Quality Incentive Program } \\ \text { CRP } & \text { Conservation Reserve Program } \\ \text { LER } & \text { Land equivalency ratio } \\ \text { GMO } & \text { Genetically modified organism } \\ \text { Yield-SAFE } & \text { Yield Estimator for Long- term Design of Silvoarable AgroForestry in Europe }\end{array}$

\section{References}

1. Foley, J.A. Can We Feed the World and Sustain the Planet? Sci. Am. 2011, 305, 60-65. [CrossRef] [PubMed]

2. Norris, K. Agriculture and biodiversity conservation: Opportunity knocks. Conserv. Lett. 2008, 1, 2-11. [CrossRef]

3. Jacobson, M.; Kar, S. Extent of Agroforestry Extension Programs in the United States. J. Ext. 2013, 51, Article 4.

4. Johnson, R.J.; Jedlicka, J.A.; Quinn, J.E.; Brandle, J.R. Global Perspectives on Birds in Agricultural Landscapes. In Integrating Agriculture, Conservation and Ecotourism: Examples from the Field; Campbell, W.B., Ortiz, S.L., Eds.; Springer: Dordrecht, The Netherlands, 2011; pp. 55-140.

5. Thomas, J.A.; Telfer, M.G.; Roy, D.B.; Preston, C.D.; Greenwood, J.J.D.; Asher, J.; Fox, R.; Clarke, R.T.; Lawton, J.H. Comparative Losses of British Butterflies, Birds, and Plants and the Global Extinction Crisis. Science 2004, 303, 1879-1881. [CrossRef] [PubMed] 
6. Daleszczyk, K.; Eycott, A.E.; Tillmann, J.E. Mammal Species Extinction and Decline: Some Current and Past Case Studies of the Detrimental Influence of Man. In Problematic Wildlife; Angelici, F.M., Ed.; Springer International Publishing: New York, NY, USA, 2016; pp. 21-44.

7. Boesch, D.; Brinsfield, R. Coastal Eutrophication and Agriculture: Contributions and Solutions. In Biological Resource Management Connecting Science and Policy; Balázs, E., Galante, E., Lynch, J.M., Schepers, J.S., Toutant, J.-P., Werner, D., Werry, P.A.T.J., Eds.; Springer: Berlin, Germany; Heidelberg, Germany, 2000; pp. 93-115.

8. McIsaac, G.F.; David, M.B.; Gertner, G.Z.; Goolsby, D.A. Eutrophication: Nitrate flux in the Mississippi River. Nature 2001, 414, 166-167. [CrossRef] [PubMed]

9. Robertson, G.P.; Paul, E.A.; Harwood, R.R. Greenhouse Gases in Intensive Agriculture: Contributions of Individual Gases to the Radiative Forcing of the Atmosphere. Science 2000, 289, 1922-1925. [CrossRef] [PubMed]

10. Reganold, J.P.; Wachter, J.M. Organic agriculture in the twenty-first century. Nat. Plants 2016, 2, 15221. [CrossRef] [PubMed]

11. Bonny, S. Genetically Modified Herbicide-Tolerant Crops, Weeds, and Herbicides: Overview and Impact. Environ. Manag. 2015, 57, 31-48. [CrossRef] [PubMed]

12. Pimentel, D.; Burgess, M. Environmental and Economic Costs of the Application of Pesticides Primarily in the United States. In Integrated Pest Management; Pimentel, D., Peshin, R., Eds.; Springer: Dordrecht, The Netherlands, 2014; pp. 47-71.

13. Di, H.J.; Cameron, K.C. Nitrate leaching in temperate agroecosystems: sources, factors and mitigating strategies. Nutr. Cycl. Agroecosystems 2002, 64, 237-256. [CrossRef]

14. Neider, R.; Benbi, D.K. Leaching Losses and Groundwater Pollution. In Carbon and Nitrogen in the Terrestrial Environment; Springer: Dordrecht, The Netherlands, 2008; pp. 219-233.

15. US EPA Clean Water Rule Litigation Statement. Available online: http://www.epa.gov/cleanwaterrule/ clean-water-rule-litigation-statement (accessed on 11 March 2016).

16. Foley, J. It's Time to Rethink America's Corn System. Available online: http:/ /www.scientificamerican.com/ article/time-to-rethink-corn/ (accessed on 24 April 2016).

17. FAO Dimensions of Need-Staple Foods: What do People Eat? Available online: http://www.fao.org/ docrep/u8480e/u8480e07.htm (accessed on 12 April 2016).

18. Altieri, M.A. The ecological role of biodiversity in agroecosystems. Agric. Ecosyst. Environ. 1999, 74, $19-31$. [CrossRef]

19. Malézieux, E.; Crozat, Y.; Dupraz, C.; Laurans, M.; Makowski, D.; Ozier-Lafontaine, H.; Rapidel, B.; de Tourdonnet, S.; Valantin-Morison, M. Mixing plant species in cropping systems: Concepts, tools and models-A review. Agron. Sustain. Dev. 2009, 29, 43-62.

20. O'Boyle, E.J. Classical economics and the Great Irish Famine: A study in limits. Forum Soc. Econ. 2006, 35, 21-53. [CrossRef]

21. Davis, A.S.; Hill, J.D.; Chase, C.A.; Johanns, A.M.; Liebman, M. Increasing Cropping System Diversity Balances Productivity, Profitability and Environmental Health. PLoS ONE 2012, 7, e47149. [CrossRef] [PubMed]

22. Jacobsen, S.-E.; Sørensen, M.; Pedersen, S.M.; Weiner, J. Feeding the world: Genetically modified crops versus agricultural biodiversity. Agron. Sustain. Dev. 2013, 33, 651-662. [CrossRef]

23. Amundson, R.; Berhe, A.A.; Hopmans, J.W.; Olson, C.; Sztein, A.E.; Sparks, D.L. Soil and human security in the 21st century. Science 2015, 348, 1261071. [CrossRef] [PubMed]

24. Hertel, T.W. The challenges of sustainably feeding a growing planet. Food Secur. 2015, 7, 185-198. [CrossRef]

25. FAO. Energy-Smart Food at FAO: An Overview. Available online: http://www.fao.org/docrep/015/an913e/ an913e00.htm (accessed on 27 April 2016).

26. Elser, J.; Bennett, E. Phosphorus cycle: A broken biogeochemical cycle. Nature 2011, 478, 29-31. [CrossRef] [PubMed]

27. Cordell, D.; White, S. Peak Phosphorus: Clarifying the Key Issues of a Vigorous Debate about Long-Term Phosphorus Security. Sustainability 2011, 3, 2027-2049. [CrossRef]

28. Frison, E.A.; Cherfas, J.; Hodgkin, T. Agricultural Biodiversity Is Essential for a Sustainable Improvement in Food and Nutrition Security. Sustainability 2011, 3, 238-253. [CrossRef] 
29. Beddington, J.; Asaduzzaman, M.; Clark, M.; (Eds.) Achieving Food Security in the Face of Climate Change: Final report from the Commission on Sustainable Agriculture and Climate Change. AGRIS: Rome, Italy, 2012.

30. Verchot, L.V.; Noordwijk, M.V.; Kandji, S.; Tomich, T.; Ong, C.; Albrecht, A.; Mackensen, J.; Bantilan, C.; Anupama, K.V.; Palm, C. Climate change: Linking adaptation and mitigation through agroforestry. Mitig. Adapt. Strateg. Glob. Change 2007, 12, 901-918. [CrossRef]

31. Muschler, R.G. Agroforestry: Essential for Sustainable and Climate-Smart Land Use? In Tropical Forestry Handbook; Springer: Berlin, Germany; Heidelberg, Germany, 2015.

32. Brewbaker, J.L. Diseases of maize in the wet lowland tropics and the collapse of the Classic Maya civilization. Econ. Bot. 1979, 33, 101-118. [CrossRef]

33. Wilkinson, T.J. Environmental Fluctuations, Agricultural Production and Collapse: A View from Bronze Age Upper Mesopotamia. In Third Millennium BC Climate Change and Old World Collapse; Dalfes, H.N., Kukla, G., Weiss, H., Eds.; NATO ASI Series; Springer: Berlin, Germany; Heidelberg, Germany, 1997; pp. 67-106.

34. Nandwani, D.; Nwosisi, S. Global Trends in Organic Agriculture. In Organic Farming for Sustainable Agriculture; Nandwani, D., Ed.; Sustainable Development and Biodiversity; Springer International Publishing: New York, NY, USA, 2016; pp. 1-35.

35. McGee, J.A. Does certified organic farming reduce greenhouse gas emissions from agricultural production? Agric. Hum. Values 2014, 32, 255-263. [CrossRef]

36. USDA. Introduction to Organic Practices 2015. Available online: https://www.ams.usda.gov/publications / content/introduction-organic-practices (accessed on 29 April 2016).

37. Gallandt, E. Weed Management in Organic Farming. In Recent Advances in Weed Management; Chauhan, B.S., Mahajan, G., Eds.; Springer: New York, NY, USA, 2014; pp. 63-85.

38. Maeder, P.; Fliessbach, A.; Dubois, D.; Gunst, L.; Fried, P.; Niggli, U. Soil Fertility and Biodiversity in Organic Farming. Science 2002, 296, 1694-1697. [CrossRef] [PubMed]

39. Tuomisto, H.L.; Hodge, I.D.; Riordan, P.; Macdonald, D.W. Does organic farming reduce environmental impacts?-A meta-analysis of European research. J. Environ. Manag. 2012, 112, 309-320. [CrossRef] [PubMed]

40. Hole, D.G.; Perkins, A.J.; Wilson, J.D.; Alexander, I.H.; Grice, P.V.; Evans, A.D. Does organic farming benefit biodiversity? Biol. Conserv. 2005, 122, 113-130. [CrossRef]

41. Mondelaers, K.; Aertsens, J.; van Huylenbroeck, G. A meta-analysis of the differences in environmental impacts between organic and conventional farming. Br. Food J. 2009, 111, 1098-1119.

42. Kirchmann, H.; Bergström, L.; Kätterer, T.; Andrén, O.; Andersson, R. Can Organic Crop Production Feed the World? In Organic Crop Production-Ambitions and Limitations; Kirchmann, H., Bergström, L., Eds.; Springer: Dordrecht, The Netherlands, 2009; pp. 39-72.

43. Letter, D.W.; Seidel, R.; Liebhardt, W. The performance of organic and conventional cropping systems in an extreme climate year. Am. J. Altern. Agric. 2003, 18, 146-154. [CrossRef]

44. Pimentel, D.; Hepperly, P.; Hanson, J.; Douds, D.; Seidel, R. Environmental, Energetic, and Economic Comparisons of Organic and Conventional Farming Systems. BioScience 2005, 55, 573-582. [CrossRef]

45. Clark, S.; Khoshnevisan, B.; Sefeedpari, P. Energy efficiency and greenhouse gas emissions during transition to organic and reduced-input practices: Student farm case study. Ecol. Eng. 2016, 88, 186-194. [CrossRef]

46. Teasdale, J.R.; Coffman, C.B.; Mangum, R.W. Potential Long-Term Benefits of No-Tillage and Organic Cropping Systems for Grain Production and Soil Improvement. Agron. J. 2007, 99, 1297-1305. [CrossRef]

47. Reganold, J.P.; Elliott, L.F.; Unger, Y.L. Long-term effects of organic and conventional farming on soil erosion. Nature 1987, 330, 370-372. [CrossRef]

48. Muller, A.; Aubert, C. The Potential of Organic Agriculture to Mitigate the Influence of Agriculture on Global Warming-A Review. In Organic Farming, Prototype for Sustainable Agricultures; Bellon, S., Penvern, S., Eds.; Springer: Dordrecht, The Netherlands, 2014; pp. 239-259.

49. Dimitri, C. Organic Agriculture: An Agrarian or Industrial Revolution? Agric. Resour. Econ. Rev. 2010, 39, 384-395.

50. Bergström, L.; Kirchmann, H.; Aronsson, H.; Torstensson, G.; Mattsson, L. Use Efficiency and Leaching of Nutrients in Organic and Conventional Cropping Systems in Sweden. In Organic Crop Production-Ambitions and Limitations; Kirchmann, H., Bergström, L., Eds.; Springer: Dordrecht, The Netherlands, 2009; pp. 143-159.

51. Marriott, E.E.; Wander, M.M. Total and Labile Soil Organic Matter in Organic and Conventional Farming Systems. Soil Sci. Soc. Am. J. 2006, 70, 950-959. [CrossRef] 
52. Ismail, I.; Blevins, R.L.; Frye, W.W. Long-Term No-tillage Effects on Soil Properties and Continuous Corn Yields. Soil Sci. Soc. Am. J. 1994, 58, 193-198. [CrossRef]

53. Zuber, S.M.; Villamil, M.B. Meta-analysis approach to assess effect of tillage on microbial biomass and enzyme activities. Soil Biol. Biochem. 2016, 97, 176-187. [CrossRef]

54. Arnhold, S.; Lindner, S.; Lee, B.; Martin, E.; Kettering, J.; Nguyen, T.T.; Koellner, T.; Ok, Y.S.; Huwe, B. Conventional and organic farming: Soil erosion and conservation potential for row crop cultivation. Geoderma 2014, 219-220, 89-105. [CrossRef]

55. Schonbeck, M. What Is “Organic No-Till”, and Is It Practical? Available online: http:/ /articles.extension. org/pages/18526/what-is-organic-no-till-and-is-it-practical (accessed on 28 April 2016).

56. Bos, J.F.F.P.; de Haan, J.; Sukkel, W.; Schils, R.L.M. Energy use and greenhouse gas emissions in organic and conventional farming systems in The Netherlands. NJAS Wagening J. Life Sci. 2014, 68, 61-70. [CrossRef]

57. Seufert, V.; Ramankutty, N.; Foley, J.A. Comparing the yields of organic and conventional agriculture. Nature 2012, 485, 229-232. [CrossRef] [PubMed]

58. Trewavas, A. Urban myths of organic farming. Nature 2001, 410, 409-410. [CrossRef] [PubMed]

59. Lovell, S.T.; DeSantis, S.; Nathan, C.A.; Olson, M.B.; Ernesto Méndez, V.; Kominami, H.C.; Erickson, D.L.; Morris, K.S.; Morris, W.B. Integrating agroecology and landscape multifunctionality in Vermont: An evolving framework to evaluate the design of agroecosystems. Agric. Syst. 2010, 103, 327-341. [CrossRef]

60. Tilman, D. Global environmental impacts of agricultural expansion: The need for sustainable and efficient practices. Proc. Natl. Acad. Sci. USA 1999, 96, 5995-6000. [CrossRef] [PubMed]

61. Nair, P.K.R.; Garrity, D. Agroforestry-The Future of Global Land Use, Advances in Agroforestry; Springer: Dordrecht, The Netherlands, 2012; Volume 9.

62. Winans, K.S.; Tardif, A.-S.; Lteif, A.E.; Whalen, J.K. Carbon sequestration potential and cost-benefit analysis of hybrid poplar, grain corn and hay cultivation in southern Quebec, Canada. Agrofor. Syst. 2015, 89, 421-433. [CrossRef]

63. Dixon, R.K.; Winjum, J.K.; Andrasko, K.J.; Lee, J.J.; Schroeder, P.E. Integrated land-use systems: Assessment of promising agroforest and alternative land-use practices to enhance carbon conservation and sequestration. Clim. Change 1994, 27, 71-92. [CrossRef]

64. Jordan, N.R.; Davis, A.S. Middle-way strategies for sustainable intensification of agriculture. BioScience 2015, 65, 513-519. [CrossRef]

65. Baah-Acheamfour, M.; Carlyle, C.N.; Bork, E.W.; Chang, S.X. Trees increase soil carbon and its stability in three agroforestry systems in central Alberta, Canada. For. Ecol. Manag. 2014, 328, 131-139. [CrossRef]

66. Caudill, S.A.; DeClerck, F.J.A.; Husband, T.P. Connecting sustainable agriculture and wildlife conservation: Does shade coffee provide habitat for mammals? Agric. Ecosyst. Environ. 2015, 199, 85-93. [CrossRef]

67. Brandle, J.R.; Schoeneberger, M.M. Working Trees: Supporting Agriculture and Healthy Landscapes. J. Trop. For. Sci. 2014, 26, 305-308.

68. Jose, S.; Gold, M.A.; Garrett, H.E. The Future of Temperate Agroforestry in the United States. In Agroforestry-The Future of Global Land Use; Nair, P.K.R., Garrity, D., Eds.; Springer: Dordrecht, The Netherlands, 2012; pp. 217-245.

69. Training Manual for Applied Agroforestry Practices, 2015 ed.; Gold, M., Cernusca, M., Hall, M., Eds.; University of Missouri Center for Agroforestry: New Franklin, MO, USA, 2006.

70. Jha, S.; Bacon, C.M.; Philpott, S.M.; Rice, R.A.; Méndez, V.E.; Läderach, P. A Review of Ecosystem Services, Farmer Livelihoods, and Value Chains in Shade Coffee Agroecosystems. In Integrating Agriculture, Conservation and Ecotourism: Examples from the Field; Campbell, W.B., Ortiz, S.L., Eds.; Springer: Dordrecht, The Netherlands, 2011; pp. 141-208.

71. Fagerholm, N.; Torralba, M.; Burgess, P.J.; Plieninger, T. A systematic map of ecosystem services assessments around European agroforestry. Ecol. Indic. 2016, 62, 47-65. [CrossRef]

72. Campbell, G.E.; Lottes, G.J.; Dawson, J.O. Design and development of agroforestry systems for Illinois, USA: Silvicultural and economic considerations. Agrofor. Syst. 1991, 13, 203-224. [CrossRef]

73. Cardinael, R.; Mao, Z.; Prieto, I.; Stokes, A.; Dupraz, C.; Kim, J.H.; Jourdan, C. Competition with winter crops induces deeper rooting of walnut trees in a Mediterranean alley cropping agroforestry system. Plant Soil 2015, 391, 219-235. [CrossRef] 
74. Dupraz, C.; Talbot, G.; Marrou, H.; Wery, J.; Roux, S.; Liagre, F.; Ferard, Y.; Nogier, A. To Mix or Not to Mix: Evidences for the Unexpected High Productivity of New Complex Agrivoltaic and Agroforestry Systems. 2011, pp. 202-203. Available online: https://www.researchgate.net/publication/230675951_To_ mix_or_not_to_mix_evidences_for_the_unexpected_high_productivity_of_new_complex_agrivoltaic_ and_agroforestry_systems (accessed on 9 December 2015).

75. Brandle, J.R.; Hodges, L.; Zhou, X.H. Windbreaks in North American agricultural systems. Agrofor. Syst. 2004, 61-62, 65-78.

76. Kallenbach, R.L.; Kerley, M.S.; Bishop-Hurley, G.J. Cumulative Forage Production, Forage Quality and Livestock Performance from an Annual Ryegrass and Cereal Rye Mixture in a Pine Walnut Silvopasture. Agrofor. Syst. 2006, 66, 43-53. [CrossRef]

77. Buergler, A.L.; Fike, J.H.; Burger, J.A.; Feldhake, C.M.; McKenna, J.R.; Teutsch, C.D. Forage Nutritive Value in an Emulated Silvopasture. Agron. J. 2006, 98, 1265-1273. [CrossRef]

78. Blanco-Canqui, H.; Lal, R. Buffer Strips. In Principles of Soil Conservation and Management; Springer: Dordrecht, The Netherlands, 2010; pp. 223-257.

79. Skelton, P.; Josiah, S.J.; King, J.W.; Brandle, J.R.; Helmers, G.A.; Francis, C.A. Adoption of riparian forest buffers on private lands in Nebraska, USA. Small-Scale For. Econ. Manag. Policy 2005, 4, 185-203.

80. Kort, J. Benefits of windbreaks to field and forage crops. Agric. Ecosyst. Environ. 1988, 22, 165-190. [CrossRef]

81. Mize, C.W.; Brandle, J.R.; Schoeneberger, M.M.; Bentrup, G. Ecological Development and function of Shelterbelts in Temperate North America. In Toward Agroforestry Design; Jose, S., Gordon, A.M., Eds.; Springer: Dordrecht, The Netherlands, 2008; pp. 27-54.

82. Zheng, X.; Zhu, J.; Xing, Z. Assessment of the effects of shelterbelts on crop yields at the regional scale in Northeast China. Agric. Syst. 2016, 143, 49-60. [CrossRef]

83. Nuberg, I.K. Effect of shelter on temperate crops: A review to define research for Australian conditions. Agrofor. Syst. 1998, 41, 3-34. [CrossRef]

84. Valdivia, C.; Poulos, C. Factors affecting farm operators' interest in incorporating riparian buffers and forest farming practices in northeast and southeast Missouri. Agrofor. Syst. 2008, 75, 61-71. [CrossRef]

85. Udawatta, R.P.; Jose, S. Carbon Sequestration Potential of Agroforestry Practices in Temperate North America. In Carbon Sequestration Potential of Agroforestry Systems; Kumar, B.M., Nair, P.K.R., Eds.; Springer: Dordrecht, The Netherlands, 2011; Volume 8, pp. 17-42.

86. Udawatta, R.P.; Kremer, R.J.; Nelson, K.A.; Jose, S.; Bardhan, S. Soil Quality of a Mature Alley Cropping Agroforestry System in Temperate North America. Commun. Soil Sci. Plant Anal. 2014, 45, 2531-2551. [CrossRef]

87. Rivest, D.; Lorente, M.; Olivier, A.; Messier, C. Soil biochemical properties and microbial resilience in agroforestry systems: Effects on wheat growth under controlled drought and flooding conditions. Sci. Total Environ. 2013, 463-464, 51-60. [CrossRef] [PubMed]

88. Udawatta, R.P.; Krstansky, J.J.; Henderson, G.S.; Garrett, H.E. Agroforestry practices, runoff, and nutrient loss: A paired watershed comparison. J. Environ. Qual. 2002, 31, 1214-1225. [CrossRef] [PubMed]

89. Jose, S. Agroforestry for ecosystem services and environmental benefits: An overview. Agrofor. Syst. 2009, 76, 1-10. [CrossRef]

90. Garrett, H.E.; McGraw, R.L.; Walter, W.D. Alley Cropping Practices. North Am. Agrofor. Integr. Sci. Pract. 2nd Ed. 2009, 133-162. [CrossRef]

91. Schultz, R.C.; Isenhart, T.M.; Colletti, J.P.; Simpkins, W.W.; Udawatta, R.P.; Schultz, P.L.; Garrett, H.E.G. Riparian and Upland Buffer Practices. In ACSESS Publications; American Society of Agronomy: Madison, WI, USA, 2009.

92. Udawatta, R.P.; Garrett, H.E.; Kallenbach, R.L. Agroforestry and grass buffer effects on water quality in grazed pastures. In Agroforestry Systems; Springer: Dordrecht, The Netherlands, 2010; Volume 79, pp. 81-87.

93. Jose, S.; Holzmueller, E.J.; Gillespie, A.R.; Garrett, H.E.G. Tree-Crop Interactions in Temperate Agroforestry. In ACSESS Publications; American Society of Agronomy: Madison, WI, USA, 2009.

94. Kim, D.-G.; Kirschbaum, M.U.F.; Beedy, T.L. Carbon sequestration and net emissions of $\mathrm{CH}_{4}$ and $\mathrm{N}_{2} \mathrm{O}$ under agroforestry: Synthesizing available data and suggestions for future studies. Agric. Ecosyst. Environ. 2016, 226, 65-78. [CrossRef]

95. Reddy, P.P. Impacts of Climate Change on Agriculture. In Climate Resilient Agriculture for Ensuring Food Security; Springer: New Delhi, India, 2015; pp. 43-90. 
96. Jose, S.; Bardhan, S. Agroforestry for biomass production and carbon sequestration: An overview. Agrofor. Syst. 2012, 86, 105-111. [CrossRef]

97. Holzmueller, E.J.; Jose, S. Biomass production for biofuels using agroforestry: Potential for the North Central Region of the United States. Agrofor. Syst. 2012, 85, 305-314. [CrossRef]

98. Mead, R.; Willey, R.W. The Concept of a "Land Equivalent Ratio" and Advantages in Yields from Intercropping. Exp. Agric. 1980, 16, 217-228. [CrossRef]

99. Haile, S.; Palmer, M.; Otey, A. Potential of loblolly pine: Switchgrass alley cropping for provision of biofuel feedstock. Agrofor. Syst. 2016. [CrossRef]

100. Graves, A.R.; Burgess, P.J.; Palma, J.H.N.; Herzog, F.; Moreno, G.; Bertomeu, M.; Dupraz, C.; Liagre, F.; Keesman, K.; van der Werf, W.; et al. Development and application of bio-economic modelling to compare silvoarable, arable, and forestry systems in three European countries. Ecol. Eng. 2007, 29, 434-449. [CrossRef]

101. Sereke, F.; Graves, A.R.; Dux, D.; Palma, J.H.N.; Herzog, F. Innovative agroecosystem goods and services: Key profitability drivers in Swiss agroforestry. Agron. Sustain. Dev. 2014, 35, 759-770. [CrossRef]

102. Bianchi, F.J.J.; Booij, C.J.; Tscharntke, T. Sustainable pest regulation in agricultural landscapes: A review on landscape composition, biodiversity and natural pest control. Proc. R. Soc. B 2006, 273, 1715-1727. [CrossRef] [PubMed]

103. Hanley, N.; Breeze, T.D.; Ellis, C.; Goulson, D. Measuring the economic value of pollination services: Principles, evidence and knowledge gaps. Ecosyst. Serv. 2015, 14, 124-132. [CrossRef]

104. Civitello, D.J.; Cohen, J.; Fatima, H.; Halstead, N.T.; Liriano, J.; McMahon, T.A.; Ortega, C.N.; Sauer, E.L.; Sehgal, T.; Young, S.; et al. Biodiversity inhibits parasites: Broad evidence for the dilution effect. Proc. Natl. Acad. Sci. USA 2015, 112, 8667-8671. [CrossRef] [PubMed]

105. Keesing, F.; Ostfeld, R.S. Is biodiversity good for your health? Science 2015, 349, 235-236. [CrossRef] [PubMed]

106. Smith, J.R. Tree Crops: A Permanent Agriculture; Island Press: Washington, DC, USA, 1950.

107. Acha, A.; Newing, H.S. Cork Oak Landscapes, Promised or Compromised Lands? A Case Study of a Traditional Cultural Landscape in Southern Spain. Hum. Ecol. 2015, 43, 601-611. [CrossRef]

108. Strong, N.; Jacobson, M.G. A case for consumer-driven extension programming: Agroforestry adoption potential in Pennsylvania. Agrofor. Syst. 2006, 68, 43-52. [CrossRef]

109. Sullivan, W.C.; Anderson, O.M.; Lovell, S.T. Agricultural buffers at the rural-urban fringe: An examination of approval by farmers, residents, and academics in the Midwestern United States. Landsc. Urban Plan. 2004, 69, 299-313. [CrossRef]

110. Valdivia, C.; Gold, M.; Zabek, L.; Arbuckle, J.; Flora, C. Human and Institutional Dimensions of Agroforestry. North Am. Agrofor. Integr. Sci. Pract. 2009. [CrossRef]

111. Trozzo, K.E.; Munsell, J.F.; Chamberlain, J.L. Landowner interest in multifunctional agroforestry Riparian buffers. In Agroforestry Systems; Springer: Dordrecht, The Netherlands, 2014; Volume 88, pp. 619-629.

112. Sereke, F.; Dobricki, M.; Wilkes, J.; Kaeser, A.; Graves, A.R.; Szerencsits, E.; Herzog, F. Swiss farmers don't adopt agroforestry because they fear for their reputation. Agrofor. Syst. 2015. [CrossRef]

113. Faulkner, P.E.; Owooh, B.; Idassi, J. Assessment of the Adoption of Agroforestry Technologies by Limited-Resource Farmers in North Carolina. J. Ext. 2014, 52, Article 5. Available online: http: //www.joe.org/joe/2014october/rb7.php (accessed on 16 October 2015).

114. Thevathasan, N.V.; Gordon, A.M.; Bradley, R.; Cogliastro, A.; Folkard, P.; Grant, R.; Kort, J.; Liggins, L.; Njenga, F.; Olivier, A.; et al. Agroforestry Research and Development in Canada: The Way Forward. In Agroforestry-The Future of Global Land Use; Nair, P.K.R., Garrity, D., Eds.; Springer: Dordrecht, The Netherlands, 2012; pp. 247-283.

115. Valdivia, C.; Barbieri, C.; Gold, M.A. Between Forestry and Farming: Policy and Environmental Implications of the Barriers to Agroforestry Adoption. Can. J. Agric. Econ. 2012, 60, 155-175. [CrossRef]

116. Current, D.A.; Brooks, K.N.; Ffolliott, P.F.; Keefe, M. Moving agroforestry into the mainstream. Agrofor. Syst. 2008, 75, 1-3. [CrossRef]

117. Quinn, C.E.; Quinn, J.E.; Halfacre, A.C. Digging Deeper: A Case Study of Farmer Conceptualization of Ecosystem Services in the American South. Environ. Manag. 2015, 56, 802-813. [CrossRef] [PubMed]

118. Chestnuts-Harvesting. Available online: http://msue.anr.msu.edu/topic/chestnuts/harvest_storage/ harvesting (accessed on 6 June 2016). 
119. Grado, S.C.; Husak, A.L. Economic Analyses of a Sustainable Agroforestry System in the Southeastern United States. In Valuing Agroforestry Systems; Advances in Agroforestry; Springer: Dordrecht, The Netherlands, 2004; pp. 39-57.

120. Prokopy, L.S.; Floress, K.; Klotthor-weinkauf, D.; Baumgart-getz, A. Determinants of agricultural best management practice adoption: Evidence from the Literature. J. Soil Water Conserv. 2008, 63, 300-311. [CrossRef]

121. Gold, M.A.; Godsey, L.D.; Josiah, S.J. Markets and marketing strategies for agroforestry specialty products in North America. In New Vistas in Agroforestry; Nair, P.K.R., Rao, M.R., Buck, L.E., Eds.; Springer: Dordrecht, The Netherlands, 2004; pp. 371-382.

122. The Savanna Institute. What Is Savannah-Based Restoration Agriculture? Available online: http://www. savannainstitute.org/about (accessed on 9 December 2015).

123. Multifunctional Landscape Analysis and Design. Available online: http://multifunctionallandscape.com/ Home_Page.html (accessed on 29 April 2016).

(C) 2016 by the authors; licensee MDPI, Basel, Switzerland. This article is an open access article distributed under the terms and conditions of the Creative Commons Attribution (CC-BY) license (http://creativecommons.org/licenses/by/4.0/). 